Journal of Nutraceuticals and Herbal Medicine

Journal Homepage: http://journals.ums.ac.id/index.php/jnhm

\title{
Antibacterial Activity of Combination of Ethanol Extract of Pepermine Leaves (Mentha piperita L.) and Amikacin Against Klebsiella pneumonia, Staphylococcus aureus, and Escherichia coli
}

\author{
Aishah Annisa Qomariyah, Peni Indrayudha* \\ Faculty of Pharmacy, Universitas Muhammadiyah Surakarta \\ Jl A. Yani Tromol Pos I, Pabelan, Kartasura, Sukoharjo 57102 \\ *E-mail: peni.indrayudha@ums.ac.id
}

\begin{abstract}
Peppermint leaves have been known to have antibacterial and antifungal activity. Amikacin is a semisynthetic derivative of kanamycin which is active against both Grampositive and Gram-negative enteric bacteria. The combination of plant extracts with antibiotics is one way or alternative to overcome bacterial resistance to antibiotics. The purpose of this study was to determine the combined effect of the ethanolic extract of peppermint (Mentha piperita L.) and amikacin against Klebsiella pneumonia, Staphylococcus aureus, and Escherichia coli as well as the compounds contained in the ethanolic extract of peppermint (Mentha piperita L.) leaves. Antibacterial activity was tested using the disk diffusion method (Kirby Bauer) and the phytochemical screening test using the tube test method. The concentration of peppermint leaf ethanol extract for the combination test was $200 \mathrm{mg} / \mathrm{mL}$ and $400 \mathrm{mg} / \mathrm{mL}$, for the concentration of amikacin used was $5 \mathrm{mg} / \mathrm{mL}$ with three comparisons made, namely 25:75, 50:50, and $75: 25$. The results showed a synergistic effect with the largest inhibition zone diameter at a ratio of $25: 75$ at a concentration of $200 \mathrm{mg} / \mathrm{mL}$, which was $36.25 \pm 2.5 \mathrm{~mm}$ on Klebsiella pneumonia bacteria. While at a concentration of $400 \mathrm{mg} / \mathrm{mL}$ the diameter of the largest inhibition zone was $40 \pm 1.63 \mathrm{~mm}$ in Klebsiella pneumoniae bacteria with a ratio of 75:25. The results of statistical tests using the t-test showed a significance value of $0.000<0.05$ so that there was a significant difference in the administration of each concentration to the resulting inhibition zone. The results of the phytochemical screening test contained alkaloids, phenolic compounds, flavonoids, tannins.
\end{abstract}

Keywords: Mentha piperita L., Klebsiella pneumonia, Staphylococcus aureus, Escherichia coli, disk diffusion, amikacin.

\section{INTRODUCTION}

Infectious diseases are still at the top of the list of causes of illness and death. One of the causes of infectious diseases is bacteria, symptoms that arise due to infection can be fever, chills, hypotension, and toxicity. Treatment for infectious diseases usually uses antibiotics, one of which is amikacin (Grayson et al., 2017). Amikacin is a semisynthetic derivative of kanamycin which is active on Gram-positive and Gram-negative enteric 
bacteria, including strains of Proteus, Enterobacter, Serratia, Mycobacterium tuberculosis (Katzung and Bertram, 2004), Staphylococcus aureus, Pseudomonas aeruginosa, and Escherichia coli (Mohamed, 2013). The difference between Gram-negative and Grampositive bacteria lies in the crystalline dye at the time of gram staining. Negative bacteria will not retain the crystal violet dye so it will turn red. Whereas in Grampositive bacteria it is purple and the cell wall is thicker (Nurhidayati et al., 2015). Amikacin belongs to the aminoglycoside group whose mechanism of action is to inhibit protein biosynthesis by irreversibly binding aminoglycosides to the $30 \mathrm{~S}$ subunit of the bacterial ribosome (Katzung and Bertram, 2004).

The increase in bacterial resistance to antibiotics is not balanced with the discovery of new antibiotics (Ventola, 2015). There are many plants that have the potential to treat infectious diseases, for example, peppermint leaves. Peppermint leaves (Mentha piperita L.) have antifungal activity on Candida albicans, Candida tropicalis, Candida glabrata, Candida parapsilosis, and Candida krusei (Furlan et al., 2010). In addition, peppermint leaves also have antibacterial activity, the diameter of the inhibition zone of distilled water extract of peppermint leaves using the disk diffusion method against the bacteria Streptococcus mutans, and Aggregatibacter actinomycetemcomitans, respectively $20.16 \pm 0.36 \mathrm{~mm}, 18.34 \pm 1.09 \mathrm{~mm}$ (Raghavan et al., 2018).

One way or alternative to overcome resistance is to combine antibiotics with plant extracts. Related to plant extracts which are traditional medicines added with synthetic isolation materials for research purposes can be developed further (BPOM, 2018). Study Stefanovi and Comic, (2012) explained that a plant when combined with antibiotics can cause a synergistic effect and have antibacterial activity, for example, research conducted on an ethanol extract of lemon balm leaves with a combination of streptomycin antibiotics showed synergistic results within the diameter of the streptomycin inhibition zone in Bacillus subtilis and Enterobacter cloacae bacteria previously $27.5 \pm 0.71 \mathrm{~mm}, 1.41 \pm 1.09 \mathrm{~mm}$ after being combined with ethanol extract of lemon balm leaves to $29.5 \pm 0.71 \mathrm{~mm}, 32.5 \pm 0.71 \mathrm{~mm}$.

Peppermint leaves (Mentha piperita L.) are still in the same family as lemon balm leaves, namely from the Lamiaceae family, while streptomycin and amikacin antibiotics belong to the aminoglycoside group. Based on this research, a combination of ethanol extract of peppermint leaf (Mentha piperita L.) and amikacin was conducted to test the antibacterial activity against Klebsiella pneumoniae, Staphylococcus aureus, and Escherichia coli bacteria.

\section{METHODS}

\section{Tools and materials}

This study uses equipment, namely glassware, Laminar Air Flow (LAF), shaker incubator (New Brunswick), weighing equipment (Ohaus), oven (Memmert), incubator (Memmert), micropipette (Socorex), autoclave (Hirayama), filter paper, water bath (Memmert), rotary evaporator (Laborota). While the materials used for this study were Klebsiella pneumoniae, Staphylococcus aureus, Escherichia coli, 96\% ethanol, peppermint leaves (Metha piperita L.) taken from Tawangmangu, Karanganyar, Central Java, amikacin, ampicillin, chloramphenicol, tetracycline, erythromycin, distilled water, blank disk, MH (Mueller Hinton) medium, BHI (Brain Heart Infusion) liquid medium, 100\% Dimethyl Sulfoxide (DMSO), 0.9\% sterile $\mathrm{NaCl}$, glacial $\mathrm{CH} 3 \mathrm{COOH}, \mathrm{H} 2 \mathrm{SO} 4$, sodium chloride 
$20 \mathrm{mg} / \mathrm{mL}$, gelatin $10 \mathrm{mg} / \mathrm{mL}, \mathrm{HCl} 1 \mathrm{~N}, \mathrm{Mg}$ powder, concentrated $\mathrm{HCl}, \mathrm{FeCl}_{3} 10 \mathrm{mg} / \mathrm{mL}$, Mayer's reagent,

\section{Research Place}

The research was conducted at the Pharmacy Microbiology Laboratory, Faculty of Pharmacy, Universitas Muhammadiyah Surakarta.

\section{Plant Determination}

The determination of peppermint leaf samples was carried out at the Plant Systematics Laboratory of the Biology Study Program, Faculty of Mathematics and Natural Sciences, Sebelas Maret University.

\section{Material Preparation}

Fresh peppermint leaves are cleaned of dirt attached to the leaves with clean water then the leaves are dried and powdered using a blender. Before being extracted, the powder was sieved first and then extracted.

\section{Extraction}

Peppermint leaf extract was made using the maceration method. The dried Simplicia powder was weighed with a weight of $300 \mathrm{~g}$, soaked in $3000 \mathrm{ml}$ of $96 \%$ ethanol using a maceration vessel, then the marinade was allowed to stand for 3 days protected from sunlight while stirring several times. After 3 days the ethanol filtrate was filtered using a Buchner funnel. Then the ethanol extract of the peppermint leaves is separated from the chlorophyll by adding hot water with a ratio of 1:1 between the hot water and the ethanolic extract of the peppermint leaves, then wait for it to cool and settle. After that, it was filtered and then evaporated using a rotary evaporator at a temperature of $45^{\circ} \mathrm{C}$ then thickened above the water bath.

\section{Sterilization of Tools and Materials}

Utensils such as glassware are washed and then dried and wrapped in paper. Heatresistant equipment such as Petri dishes, test tubes, glass beakers, and other glassware was sterilized using dry heating in an oven for 1 hour at $170^{\circ} \mathrm{C}$. Meanwhile, tools and materials that are not heat resistant such as media, tips (blue, yellow, white), dropper pipettes, and other tools are sterilized by wet heating using an autoclave at $121^{\circ} \mathrm{C}$ for 20 minutes. Ose needles and spreader glass are sterilized by burning.

\section{Preparation of Media}

The media used for this research are MH (Mueller Hinton) and BHI (Brain Heart Infusion) media. Preparation of $\mathrm{MH}$ (Mueller Hinton) Media was carried out by dissolving 1.14 grams in $30 \mathrm{~mL}$ of distilled water for each one petri dish. Meanwhile, for the manufacture of BHI (Brain Heart Infusion) media, it is done by dissolving $185 \mathrm{mg}$ in 5 $\mathrm{mL}$ of distilled water for each test tube. Then the media solution made was sterilized using an autoclave at $121^{\circ} \mathrm{C}$ for 20 minutes and then poured into a petri dish and allowed to stand at room temperature until solid. The principle of autoclaving in killing bacteria by using steam at high temperature and pressure is $121^{\circ} \mathrm{C}$, the high temperature can kill microorganisms or bacteria.

\section{Bacterial culture}

Each of the bacteria K. pneumoniae, S. aureus, and E. coli was taken one end of the round loop from the parent bacteria then streak plated on MH media (Mueller Hinton) 
then incubated for $18-24$ hours at $37^{\circ} \mathrm{C}$, after $18-24$ hours. hours and inoculated colonies growing in Petri dishes were stored in a refrigerator at $4^{\circ} \mathrm{C}$.

\section{Bacterial Suspension Preparation}

K. pneumoniae, S. aureus, and E. coli bacteria from overnight culture on MH (Mueller Hinton) plates were taken 3-5 colonies each, then a bacterial suspension was made with $5 \mathrm{ml}$ of Brain Heart Infusion (BHI) media and incubated using a shaker incubator at 200 $\mathrm{rpm}$ at $37^{\circ} \mathrm{C}$ for 2 hours. The concentration of the bacterial suspension was equalized using the Mc Farland standard of $10^{8} \mathrm{CFU} / \mathrm{mL}$ by diluting it using a sterile $0.9 \% \mathrm{NaCl}$ solution. The bacterial suspension was taken $200 \mathrm{~L}$ each time it was used for the antibacterial test.

\section{Antibiotic Sensitivity Test}

The bacterial suspension which was equivalent to the standard Mc Farland 108 $\mathrm{CFU} / \mathrm{mL}$ was taken $200 \mathrm{~L}$ and then inoculated on solid MH (Mueller Hinton) media then leveled with a spreader glass and waited for a while to dry. The antibiotic discs used were ampicillin $10 \mathrm{~g}$, chloramphenicol $30 \mathrm{~g}$, tetracycline $30 \mathrm{~g}$, erythromycin $15 \mathrm{~g}$, Amikacin $30 \mathrm{~g}$ were placed on $\mathrm{MH}$ media that had been inoculated with bacterial suspension and then incubated at $37^{\circ} \mathrm{C}$ for $18-24$ hours. The diameter of the inhibition zone formed was measured and compared with the standard of bacterial resistance to antibiotics.

\section{Production of Stock and Concentration Series of Peppermint Leaf Ethanol Extract}

The stock concentration of the peppermint leaf ethanol extract made was 800 $\mathrm{mg} / \mathrm{mL}$, the peppermint leaf ethanol extract was weighed $8 \mathrm{~g}$ and then dissolved to 10 $\mathrm{mL}$ using 100\% DMSO. The concentration series made were $200 \mathrm{mg} / \mathrm{mL}, 400 \mathrm{mg} / \mathrm{mL}$ and $800 \mathrm{mg} / \mathrm{mL}$ with $125 \mathrm{~L}$ stock-taking, $250 \mathrm{~L}$ dissolved in $100 \%$ DMSO to $500 \mathrm{~L}$ and for a concentration of $800 \mathrm{mg} / \mathrm{mL} 500 \mathrm{~L}$ was taken directly from the stock solution.

\section{Amikacin Concentration Series and Stock Preparation}

Amikacin stock with $50 \mathrm{mg} / \mathrm{mL}$ concentration was prepared by dissolving $500 \mathrm{mg}$ amikacin with aqua pro injection until the volume was $10 \mathrm{~mL}$. The concentration series that were made were $5 \mathrm{mg} / \mathrm{mL}, 10 \mathrm{mg} / \mathrm{mL}$, and $20 \mathrm{mg} / \mathrm{mL}$ from the stock solution taken as much as $100 \mathrm{~L}, 200 \mathrm{~L}, 400 \mathrm{~L}$ and dissolved with the aqua pro injection to $1 \mathrm{~mL}$.

\section{Comparison Series of Peppermint Leaf Ethanol Extract and Amikacin}

Comparison of the concentration series of peppermint leaf ethanol extract with amikacin made 3 comparisons, namely 25:75, 50:50, 75:25. The concentration of peppermint leaf ethanol extract used was $200 \mathrm{mg} / \mathrm{mL}$ and $400 \mathrm{mg} / \mathrm{mL}$, while the amikacin concentration series used was $5 \mathrm{mg} / \mathrm{mL}$, with the total volume of the combination in disk $20 \mathrm{~L}$. The intake for the combination test of each comparison is 5 L:15 L, 10 L:10 L, 15 L:5 L.

\section{Antibacterial Activity Test of Peppermint Leaf Ethanol Extract and Amikacin with Disk Diffusion Method}

Each suspension of K. pneumoniae, S. aureus, and E. coli bacteria was taken $200 \mathrm{~L}$ then inoculated on MH media and then flattened using a spreader glass, and waited for a while to dry. The DMSO control 100\% and the concentration series of peppermint leaf ethanol extract were each taken $20 \mathrm{~L}$ and then dripped onto a blank disk that had been placed on MH media that had been inoculated with bacterial suspension. After that, it 
was incubated for $18-24$ hours at $37^{\circ} \mathrm{C}$ and then observed and measured the diameter of the inhibition zone formed. Pretreatment of the amikacin concentration series was carried out in the same way as the peppermint leaf ethanol extract, but the negative control used was aqua pro injection. This single test was replicated 4 times.

\section{Antibacterial Activity Test Combination of Peppermint Leaf Ethanol Extract and Amikacin}

Bacterial suspensions of K. pneumoniae, S. aureus, and E. coli which were equivalent to the standard Mc Farland $10^{8} \mathrm{CFU} / \mathrm{mL}$ were taken $200 \mathrm{~L}$ then inoculated on MH media then leveled with a spreader glass, and waited for it to dry. The ethanol extract of peppermint leaves used were concentrations of $200 \mathrm{mg} / \mathrm{mL}$ and $400 \mathrm{mg} / \mathrm{mL}$ then the volume of the combination of ethanolic extract of peppermint leaves with amikacin was in the ratio $(25: 75,50: 50,75: 25)$ with positive control of $5 \mathrm{mg} / \mathrm{mL}$, The negative control used was $100 \%$ DMSO and aqua pro injection, each of which was dripped on a blank disk of $20 \mathrm{~L}$ which had been placed on MH media with bacterial suspension inoculated. Then it was incubated for $18-24$ hours at $37^{\circ} \mathrm{C}$ and then observed and measured the diameter of the inhibition zone formed.

\section{Phytochemical Screening}

\section{a. Alkaloid Test}

The extract was weighed as much as $40 \mathrm{mg}$ then added with $2 \mathrm{~mL}$ of chloroform and ammonia and then filtered. The mixture is then added 3-5 drops of concentrated $\mathrm{H}_{2} \mathrm{SO}_{4}$ and then shaken until two layers are formed. The acid portion (bottom) was taken and added with 4-5 drops of Mayer and Dragendorff reagents each. The sample contains alkaloids if a precipitate is formed, using Mayer's reagent the precipitate is white, and Dragendorff's reagent the precipitate formed is yellow-red.

\section{b. Phenolic Test}

The ethanol extract of peppermint leaves was weighed as much as $40 \mathrm{mg}$ and then added with $10 \mathrm{mg} / \mathrm{mL} \mathrm{FeCl}_{3}$ solution as much as 10 drops. The presence of phenolic in the sample if the solution is green, blue, purple, dark black, or red.

\section{c. Flavonoid Test}

Peppermint leaf ethanol extract was weighed $40 \mathrm{mg}$ then added $100 \mathrm{~mL}$ of hot water and then boiled for 5 minutes and filtered. Then $5 \mathrm{~mL}$ was taken, added with $50 \mathrm{mg}$ of $\mathrm{Mg}$ powder and $1 \mathrm{~mL}$ of concentrated $\mathrm{HCl}$, and then shaken vigorously. Observe the color changes that occur, the presence of flavonoids if the solution is yellow or orange and red.

\section{d. Saponin Test}

Extract $40 \mathrm{mg}$ added with $10 \mathrm{~mL}$ of water then shaken for 1 minute, then added with $\mathrm{HCl} 1 \mathrm{~N} 2$ drops. Observe the foam formed for 7 minutes, if the foam formed is stable in the extract containing saponins.

\section{e. Tannin Test}

Peppermint leaf ethanol extract was taken sufficiently then added $1 \mathrm{~mL}$ of 20 $\mathrm{mg} / \mathrm{mL}$ sodium chloride solution and then added $5 \mathrm{~mL}$ of $10 \mathrm{mg} / \mathrm{mL}$ gelatin. The formation of a precipitate indicates the presence of tannins in the sample. 


\section{f. Steroid or Titerpenoid Test}

Forty mg of extract was weighed and then 10 drops of glacial $\mathrm{CH}_{3} \mathrm{COOH}$ and 2 drops of $\mathrm{H}_{2} \mathrm{SO}_{4}$ were added and then shaken gently. Extracts containing steroids are indicated by green or blue color in the solution, extracts indicate the presence of triterpenoids if the solution formed is red or purple.

\section{Data analysis}

\section{a. Antibacterial Activity Data Analysis}

Data analysis was performed by measuring the diameter of the inhibition zone on the ethanol extract of peppermint leaves, amikacin, DMSO, and the combination of the ethanolic extract of peppermint leaves with amikacin. The results showed synergism if the diameter of the combined inhibition zone was greater than that without the combination.

\section{b. Phytochemical Screening Data Analysis}

Data analysis to determine the compounds contained in the extract was carried out by looking at the test reaction results and color changes in the test tube.

\section{RESULTS AND DISCUSSION}

\section{Plant Determination}

Plant determination was carried out at the Plant Systematics Laboratory of the Biology Study Program, Faculty of Mathematics and Natural Sciences, Sebelas Maret University. The purpose of plant determination is to determine the correct identity of a plant used in research and to avoid errors in collecting samples for research (Diniatic, 2015). The key to the determination of these plants is as follows:

\section{Identification key:}

1b-2b-3b-4b-12b-13b-14b-17b-18b-19b-20b-21b-22b-23b-24b-25b-26b-27a-28b-29b-30b31b-403b-404b-405a- 406b-409a-410b-411b

190.Lamiaceae 1b-2b-3a-4c-5b-7b-8c-11a-12a-13b-15c-20b-21b-23b-24b 22.0cimum $1 b-2 b-4 b-5 b-6 a-7 b-8 a$

7.Mentha $x$ piperitaL.

The results of the identification key indication that the plant used for this research is Mentha piperita L.

\section{Extraction}

Extracts were made by the maceration method using $96 \%$ ethanol as solvent. Ethanol is a mixed hydroalcoholic solvent that can dissolve substances that are soluble in alcohol and water so that it can extract the active compounds contained in plant simplicia (Ansel, 1989). The plant parts used in this study were leaves that contained chlorophyll compounds. Chlorophyll is an unstable compound so it is necessary to separate chlorophyll (Ernaeni et al., 2012). The yield of the extract obtained was $9.333 \%$ from 300 grams of dried simplicia peppermint leaves obtained 28 grams of thick extract. 


\section{Bacterial Sensitivity Test To Antibiotics}

The sensitivity test is used to determine the sensitivity and resistance of bacteria to antibiotics (Cahyono and Indrayudha, 2013), the bacteria used were $K$. pneumoniae, $S$. aureus, and E. coli using the disk diffusion method. The sensitivity test used several antibiotic discs, namely Ampicillin, Chloramphenicol, Tetracycline, Erythromycin, and Amikacin. The diameter of the inhibition zone from the results of the bacterial sensitivity test to antibiotics can be seen in Figure 1.

The results of the bacterial sensitivity test to antibiotics (Table 1) on K. Pneumoniae bacteria showed intermediates on ampicillin and tetracycline antibiotic disks while showing sensitivity on chloramphenicol, erythromycin, and amikacin antibiotic disks. $S$. aureus bacteria showed sensitivity to all antibiotic disks, while E. coli bacteria showed intermediates to ampicillin antibiotic disks, sensitivity to chloramphenicol, tetracycline, amikacin antibiotic disks, and resistance to erythromycin antibiotic disks, bacterial resistance to erythromycin due to the methylation process on rRNA receptors resulting in loss of receptors on ribosomes (Jawetz et al., 2005).

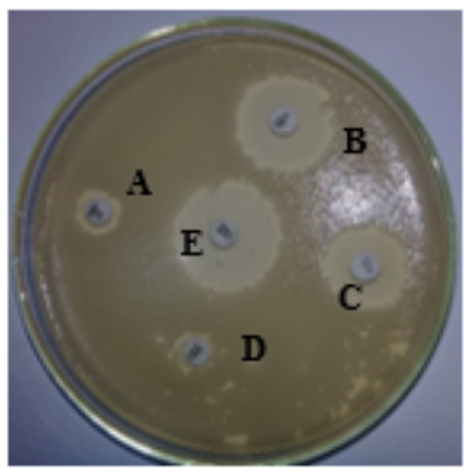

I

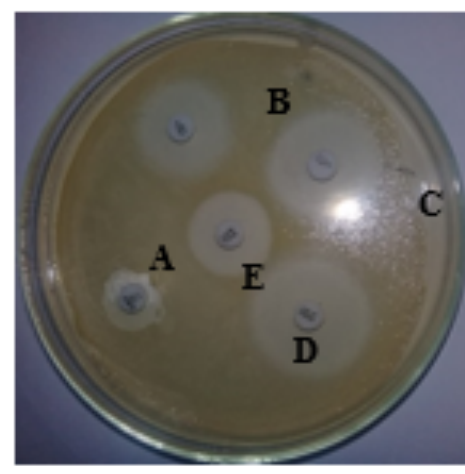

II

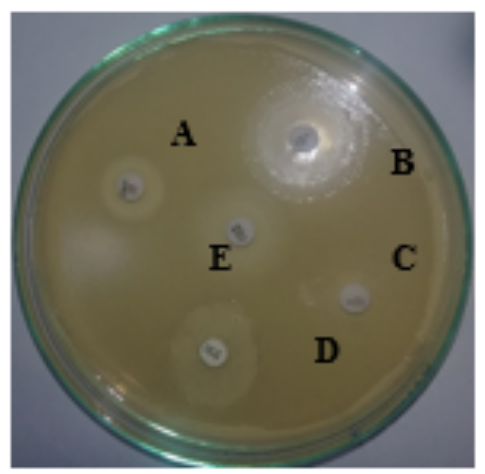

III

Picture 1. Bacterial sensitivity test results to antibiotics Ampicillin (A), Chloramphenicol (B), Erythromycin (C), Tetracycline (D), Amikacin (E)

Description: Klebsiella pneumoniae (I), Staphylococcus aureus (II), Escherichia coli (III)

Table 1. Bacterial Sensitivity Test Results Klebsiella pneumoniae, Staphylococcus aureus, and Escherichia coli

\begin{tabular}{|c|c|c|c|c|c|c|}
\hline \multirow{2}{*}{ Bacteria } & \multirow{2}{*}{ Antibiotic Disc } & \multicolumn{3}{|c|}{$\begin{array}{c}\text { Bacterial inhibition zone } \\
\text { standard (mm) }\end{array}$} & \multirow{2}{*}{$\begin{array}{c}\text { Inhibition } \\
\text { zone } \\
\text { diameter } \\
(\mathrm{mm}) \\
\end{array}$} & \multirow{2}{*}{ Information } \\
\hline & & $\begin{array}{l}\text { Resis- } \\
\text { tance }\end{array}$ & $\begin{array}{c}\text { Inter- } \\
\text { mediate }\end{array}$ & $\begin{array}{c}\text { Sensi- } \\
\text { tive }\end{array}$ & & \\
\hline Klebsiella & Ampicillin $10 \mathrm{~g}$ & 13 & $14-16$ & 17 & 16 & Intermediates \\
\hline \multirow[t]{4}{*}{ Pneumoniae } & Chloramphenicol $30 \mathrm{~g}$ & 12 & $13-17$ & 18 & 21 & sensitive \\
\hline & Tetracycline $30 \mathrm{~g}$ & 11 & $12-14$ & 15 & 12 & Intermediates \\
\hline & Erythromycin $15 \mathrm{~g}$ & 15 & $16-20$ & 21 & 21 & sensitive \\
\hline & Amikacin $30 \mathrm{~g}$ & 14 & $15-16$ & 17 & 27 & sensitive \\
\hline Staphylococc & Ampicillin $10 \mathrm{~g}$ & 13 & $14-16$ & 17 & 19 & sensitive \\
\hline \multirow[t]{4}{*}{ us aureus } & Chloramphenicol $30 \mathrm{~g}$ & 12 & $13-17$ & 18 & 22 & sensitive \\
\hline & Tetracycline $30 \mathrm{~g}$ & 11 & $12-14$ & 15 & 27.5 & sensitive \\
\hline & Erythromycin $15 \mathrm{~g}$ & 15 & $16-20$ & 21 & 25.5 & sensitive \\
\hline & Amikacin $30 \mathrm{~g}$ & 14 & $15-16$ & 17 & 20 & sensitive \\
\hline
\end{tabular}




\begin{tabular}{llccccl}
\hline Bacteria & \multicolumn{1}{c}{ Antibiotic Disc } & \multicolumn{3}{c}{$\begin{array}{c}\text { Bacterial inhibition zone } \\
\text { standard (mm) }\end{array}$} & $\begin{array}{c}\text { Inhibition } \\
\text { zone }\end{array}$ & Information \\
\hline Escherichia & Ampicillin 10 g & 13 & $14-16$ & 17 & 15 & Intermediates \\
coli & Chloramphenicol 30 g & 12 & $13-17$ & 18 & 27.5 & sensitive \\
& Tetracycline 30 g & 11 & $12-14$ & 15 & 28 & sensitive \\
& Erythromycin 15 g & 15 & $16-20$ & 21 & 6 & resistance \\
& Amikacin 30 g & 14 & $15-16$ & 17 & 20 & sensitive \\
\hline
\end{tabular}

\section{Note: Inhibition zone diameter including disk diameter $(6 \mathrm{~mm})$}

\section{Antibacterial Activity of Peppermint Leaf Ethanol Extract and Amikacin}

The antibacterial test of single peppermint leaf ethanol extract and amikacin single test was carried out to determine the antibacterial activity of the peppermint leaf ethanol extract and the sensitivity of the amikacin antibiotic used against bacteria (Hanik et al., 2012). The bacteria used were K. pneumoniae, S. aureus, and E. coli. The test was carried out using the disk diffusion method, this method was also used by AL-sum and Al-arfaj, (2013) and also Raghavan et al., (2018).

The concentration of peppermint leaf ethanol extract used was $200 \mathrm{mg} / \mathrm{mL}, 400$ $\mathrm{mg} / \mathrm{ml}$, and $800 \mathrm{mg} / \mathrm{mL}$ with each disc concentration of $4 \mathrm{mg} /$ disk, $8 \mathrm{mg} /$ disk and 16 $\mathrm{mg} /$ disk. The positive control used amikacin $20 \mathrm{mg} / \mathrm{mL}$ with a concentration of 0.4 $\mathrm{mg} /$ disk per disk, and the negative control used 100\% DMSO. The concentrations of amikacin used were $5 \mathrm{mg} / \mathrm{mL}, 10 \mathrm{mg} / \mathrm{mL}, 20 \mathrm{mg} / \mathrm{mL}$, with the concentration of each disk being $0.1 \mathrm{mg} /$ disk, $0.2 \mathrm{mg} /$ disk and $0.4 \mathrm{mg} /$ disk, the negative control used was used aqua pro injection. The results of the diameter of the inhibition zone were influenced by the ethanol extract of peppermint leaves on the growth of K. pneumoniae, S. aureus, and E. coli bacteria.

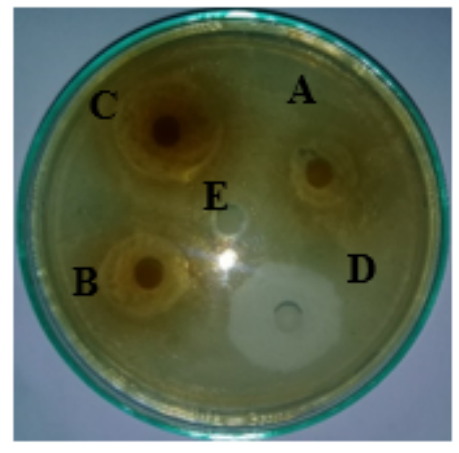

(I)

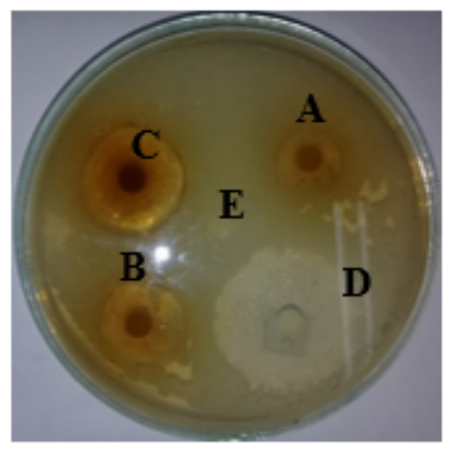

(II)

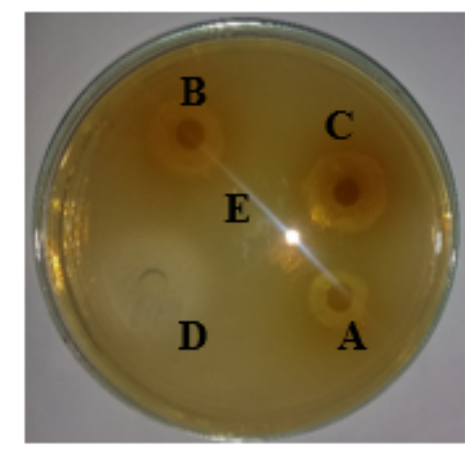

(III)

Picture 2. The results of the antibacterial activity test of peppermint leaf ethanol extract with a concentration of $4 \mathrm{mg} / \operatorname{disk}(\mathrm{A})$, concentration $8 \mathrm{mg} / \operatorname{disk}(\mathrm{B})$, concentration $16 \mathrm{mg} / \operatorname{disk}(\mathrm{C})$, amikacin $0.4 \mathrm{mg} / \operatorname{disk}(\mathrm{D})$, DMSO (E)

Description: Klebsiella pneumoniae (I), Staphylococcus aureus (II), Escherichia coli (III)

Table 2. The results of the antibacterial activity of peppermint leaf ethanol extract

\begin{tabular}{cccc}
\hline $\begin{array}{c}\text { Test Material } \\
\text { mg/disk }\end{array}$ & $\begin{array}{c}\text { K. pneumoniae inhibition } \\
\text { zone diameter }(\mathbf{m m})\end{array}$ & $\begin{array}{c}\text { S. aureus inhibition } \\
\text { zone diameter } \mathbf{( m m})\end{array}$ & $\begin{array}{c}\text { E. coli inhibition zone } \\
\text { diameter } \mathbf{( m m})\end{array}$ \\
\hline Extract 4 & $18 \pm 1.63$ & $18.5 \pm 1$ & $16.25 \pm 0.5$ \\
Extract 8 & $20.5 \pm 0.58$ & $22.25 \pm 0.5$ & $19.75 \pm 0.5$ \\
Extract 16 & $25.5 \pm 0.58$ & $25.25 \pm 0.5$ & $25.25 \pm 0.5$ \\
Amikacin 0.4 & $36.25 \pm 2.5$ & $26.5 \pm 2.38$ & $23 \pm 0$ \\
\hline Journal of Nutraceuticals and Herbal Medicine, ISSN 2615-4609 & \\
\hline
\end{tabular}




\begin{tabular}{cccc}
\hline Test Material & K. pneumoniae inhibition & S. aureus inhibition & E. coli inhibition zone \\
\hline DMSO & 6 & 6 & 6 \\
\hline
\end{tabular}

Note: Inhibition zone diameter including disk diameter $(6 \mathrm{~mm})$, is the average of 4 times of replication

The single test results of antibacterial activity of peppermint leaf ethanol extract against K. pneumoniae, S.aureus, and E.coli bacteria (Table 2) at the tested concentration formed a radical inhibition zone (Figure 2), meaning that the peppermint leaf ethanol extract has antibacterial activity. The diameter of the inhibition zone of peppermint leaf ethanol extract had the greatest activity at a concentration of $800 \mathrm{mg} / \mathrm{mL}$ with a concentration of $16 \mathrm{mg} /$ disk per disk, which was equal to $25.5 \pm 0.58 \mathrm{~mm}$ in $K$. pneumoniae bacteria, $25.25 \pm 0.5 \mathrm{~mm}$ in $S$. aureus, and E.coli. The greater the concentration tested, the greater the diameter of the inhibition zone, this is influenced by the large number of compounds contained in the disk so that the peppermint leaf ethanol extract is able to inhibit the growth of K. pneumoniae, S. aureus, and E. coli bacteria as well.

The results of the diameter of the inhibition zone on the ethanol extract of peppermint leave formed (Figure 2) were compared with the positive control used, namely amikacin $20 \mathrm{mg} / \mathrm{mL}$ with a concentration of $0.4 \mathrm{mg} /$ disk each with an inhibition zone of $36.25 \pm 2.5 \mathrm{~mm}$ at $K$. pneumoniae, $26.5 \pm 2.38 \mathrm{~mm}$ in $S$. aureus, and $23 \pm 0 \mathrm{~mm}$ in $E$. coli. While the negative control used was $100 \%$ DMSO as a solvent for peppermint leaf ethanol extract that did not show the diameter of the inhibition zone so that the resulting inhibition zone was not influenced by the solvent (Handoko et al., 2013). The diameter of the inhibition zone in the ethanol extract of peppermint leaves was smaller than the positive control, but the ethanolic extract of peppermint leaves still had antibacterial activity because it could inhibit the growth of $K$. pneumoniae, $S$. aureus, and $E$. coli bacteria.

Research conducted by Al-sum and Al-arfaj, (2013) Peppermint leaf aqueous extract with a concentration of $200 \mathrm{mg} / \mathrm{ml}$ can inhibit the growth of $K$. pneumoniae, S. aureus, and E. coli bacteria, with inhibition zone diameters of $8 \mathrm{~mm}, 18 \mathrm{~mm}$, and $14 \mathrm{~mm}$, respectively. Results of research conducted Al-sum and Al-arfaj, (2013)The diameter of the resulting inhibition zone is smaller than the test results on the ethanol extract of peppermint leaves in this study. This can be caused by differences in the solvents used, in this study $96 \%$ ethanol solvent was used, and leaves were obtained from the Indonesian region, while in this study Al-sum and Al-arfaj, (2013) The solvent used was water, and the leaves used were obtained from the Riyadh garden area in Saudi Arabia.

The results of a single test of amikacin on bacteria $K$. pneumoniae, $S$. aureus, and $E$. coli (Table 3) with a concentration of $5 \mathrm{mg} / \mathrm{mL}, 10 \mathrm{mg} / \mathrm{mL}, 20 \mathrm{mg} / \mathrm{mL}$ with a concentration of $0.1 \mathrm{mg} /$ disk per disk, $0,2 \mathrm{mg} / \mathrm{disk}, 0.4 \mathrm{mg} /$ disk indicated the zone of inhibition respectively $31.5 \pm 2.38 \mathrm{~mm}, 33.75 \pm 1.5 \mathrm{~mm}, 38.75 \pm 2.98$ in bacteria $K$. pneumoniae, $23.25 \pm 1.25 \mathrm{~mm}, 26.25 \pm 1.25 \mathrm{~mm}, 28 \pm 0.81 \mathrm{~mm}$ in bacteriaS. aureus and $25 \pm 0$ $\mathrm{mm}, 26.75 \pm 1.5 \mathrm{~mm}, 30 \pm 0 \mathrm{~mm}$ in bacteria $E$. coli. The negative control used was Aqua pro injection as the solvent did not show an inhibition zone, so the resulting inhibition zone was not affected by the solvent. Based on the diameter of the resulting inhibition zone (Figure 3), a concentration of $5 \mathrm{mg} / \mathrm{mL}(0.1 \mathrm{mg} /$ disk) was chosen for the combination test, a concentration of $5 \mathrm{mg} / \mathrm{mL}(0.1 \mathrm{mg} /$ disk $)$ was chosen because the diameter of the 
resulting inhibition zone was large when the largest concentration was used, which was $20 \mathrm{mg} / \mathrm{mL}$ with a concentration of $0.4 \mathrm{mg} /$ disk per disk when combined the diameter of the resulting inhibition zone would be larger.

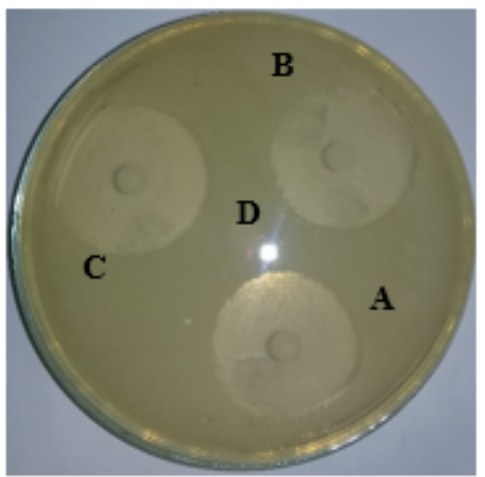

(I)

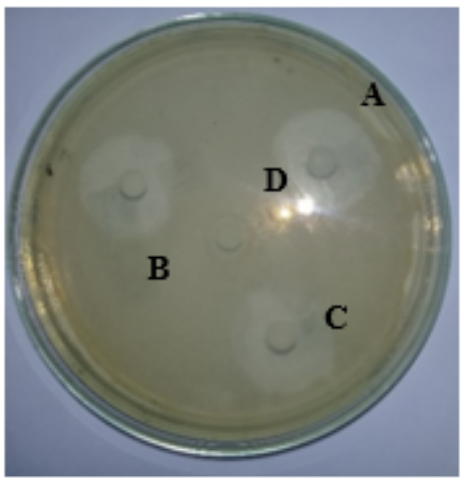

(II)

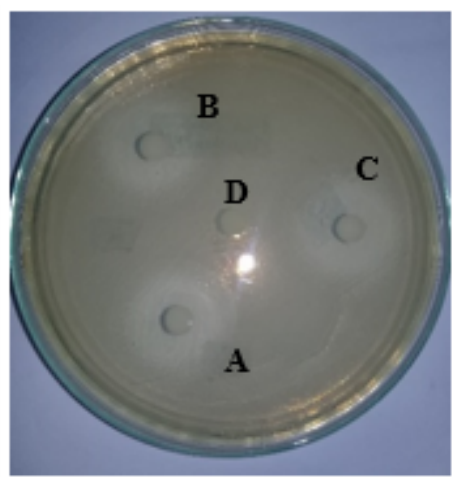

(III)

Picture 3. Preliminary test results of amikacin $0.1 \mathrm{mg} / \operatorname{disk}(\mathrm{A}), 0.2 \mathrm{mg} / \operatorname{disk}(\mathrm{B}), 0.4$ $\mathrm{mg} / \operatorname{disk}(\mathrm{C})$, aqua pro injection (D)

Description: Klebsiella pneumoniae (I), Staphylococcus aureus (II), Escherichia coli (III)

Table 3. Amikacin preliminary test results

\begin{tabular}{lccc}
\hline $\begin{array}{c}\text { Test Material } \\
\text { mg/disk }\end{array}$ & $\begin{array}{c}\text { K. pneumoniae } \\
\text { inhibition zone } \\
\text { diameter }(\mathbf{m m})\end{array}$ & $\begin{array}{c}\text { S. aureus inhibition } \\
\text { zone diameter }(\mathbf{m m})\end{array}$ & $\begin{array}{c}\text { E. coli inhibition } \\
\text { zone diameter }(\mathbf{m m})\end{array}$ \\
\hline Amikacin 0.1 & $31.5 \pm 2.38$ & $23.25 \pm 1.25$ & $25 \pm 0$ \\
Amikacin 0.2 & $33.75 \pm 1.5$ & $26.25 \pm 1.25$ & $26.75 \pm 1.5$ \\
Amikacin 0.4 & $38.75 \pm 2.98$ & $28 \pm 0.81$ & $30 \pm 0$ \\
Aqua pro injection & 6 & 6 & 6 \\
\hline
\end{tabular}

Note: Inhibition zone diameter including disk diameter $(6 \mathrm{~mm})$, is the average of 4 times of replication

\section{Antibacterial Activity Combination of Peppermint Leaf Ethanol Extract and Amikacin}

The purpose of the antibacterial activity test of the combination of peppermint leaf ethanol extract and amikacin was carried out to determine the effect of antibacterial activity after being combined rather than given alone. This test was carried out using the disk diffusion method with a concentration of peppermint leaf ethanol extract of 200 $\mathrm{mg} / \mathrm{mL}$ and $400 \mathrm{mg} / \mathrm{mL}$ with a concentration of each disk of $4 \mathrm{mg} /$ disk and $8 \mathrm{mg} / \mathrm{disk}$ combined with amikacin at a concentration of $5 \mathrm{mg} / \mathrm{mL}$ with a concentration of 0 , each disk. $1 \mathrm{mg} /$ disk. The comparison between the ethanol extract of peppermint leaves and amikacin was 25:75, 50:50, 75:25 with a total volume of $20 \mathrm{~L}$, the positive control used was amikacin $5 \mathrm{mg} / \mathrm{mL}$ with a concentration of $0.1 \mathrm{mg} /$ disk each, while the negative control was used. used DMSO and aqua pro injection.

The results of the combination antibacterial activity test on $K$. pneumoniae, $S$. aureus, and E. coli bacteria (Tables 4 and 5) showed that the diameter of the inhibition zone was larger than that of the ethanol extract of peppermint leaves alone. Inhibition zone diameter of peppermint leaf ethanol extract concentration of $200 \mathrm{mg} / \mathrm{mL}$ (4 mg/disk) in combination with amikacin $5 \mathrm{mg} / \mathrm{mL}(0.1 \mathrm{mg} /$ disk $)$ at a ratio of 25:75, 50:50, 75:25 in bacteria $\mathrm{K}$. pneumoniae in a row, namely36.25 $\pm 2.5 \mathrm{~mm} ; 32 \pm 1.5 \mathrm{~mm} ; 34 \pm 1.71 \mathrm{~mm}$. 
Whereas in bacteriaS. aureus that is $27.25 \pm 1.71 \mathrm{~mm} ; 27.25 \pm 1.89 \mathrm{~mm} ; 26 \pm 1.41 \mathrm{~mm}$ and in bacteriaE. Coli that is $26.75 \pm 1.5 \mathrm{~mm} ; 28 \pm 1.16 \mathrm{~mm} ; 26.75 \pm 2.62 \mathrm{~mm}$. Diameter of single inhibition zone of amikacin concentration $5 \mathrm{mg} / \mathrm{mL}$ in bacteria $K$. pneumoniae, S. aureus, and $E$. coli, respectively, namely $30 \pm 0 ; 20 \pm 0 ; 20 \pm 0$. At concentrations of $200 \mathrm{mg} / \mathrm{mL}$ (4 $\mathrm{mg} /$ disk) and $400 \mathrm{mg} / \mathrm{mL}$ (8 mg/disk) with amikacin $5 \mathrm{mg} / \mathrm{mL}(0.1 \mathrm{mg} /$ disk $)$ resulted in a larger diameter than given without the combination. These data indicate that the combination of peppermint leaf ethanol extract with amikacin antibiotics shows a synergistic effect.

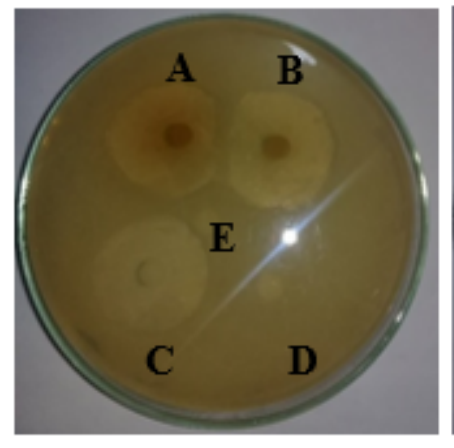

(I)

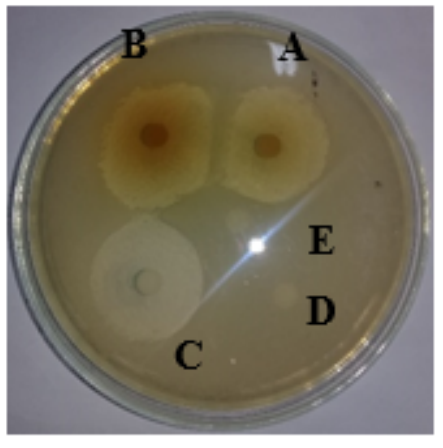

(II)

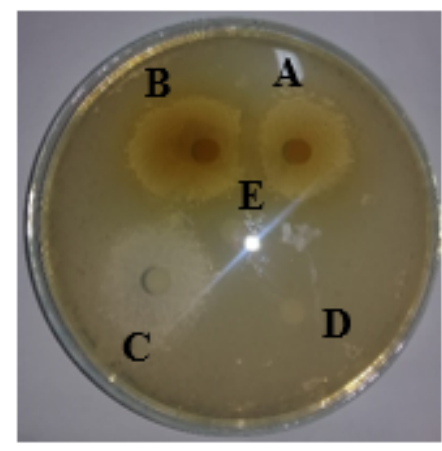

(III)

Picture 3. The results of the antibacterial activity of the combination of peppermint leaf ethanol extract and amikacin against bacteria K. pneumoniae $4 \mathrm{mg} / \mathrm{disk}(\mathrm{A}), 8 \mathrm{mg} / \mathrm{disk}$

(B), Amikacin $0.1 \mathrm{mg} / \operatorname{disk}(\mathrm{C})$, Aqua pro injection (D), DMSO (E)

Note: Comparison 25:75 (I), Comparison 50:50 (II), Comparison 75:25 (III)

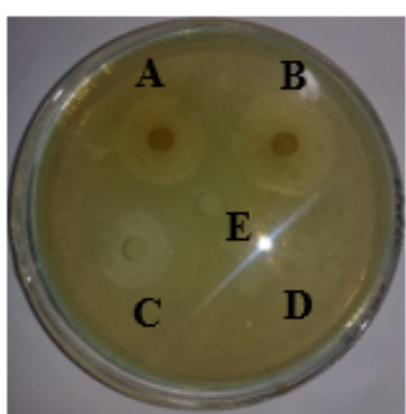

(I)

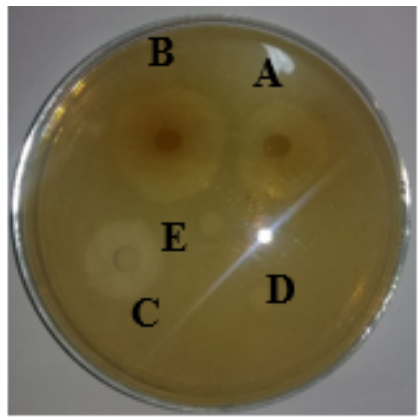

(II)

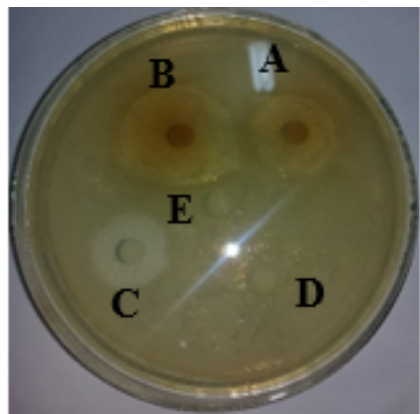

(III)

Picture 4. The results of the antibacterial activity of the combination of peppermint leaf ethanol extract and amikacin against $\mathrm{S}$. aureus bacteria $4 \mathrm{mg} /$ disk (A), $8 \mathrm{mg} /$ disk (B), Amikacin $0.1 \mathrm{mg} /$ disk (C), Aqua pro injection (D), DMSO (E)

Note: Comparison 25:75 (I), Comparison 50:50 (II), Comparison 75:25 (III) 


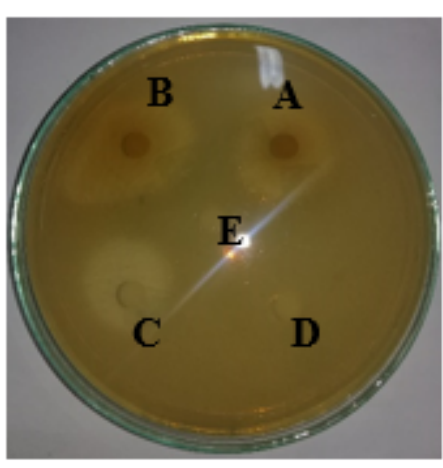

(I)

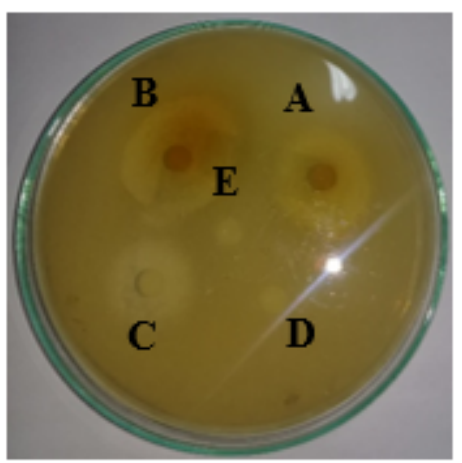

(II)

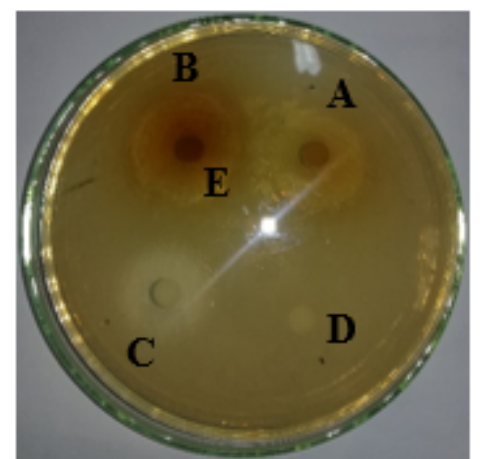

(III)

Picture 5. The results of the antibacterial activity of the combination of peppermint leaf ethanol extract and amikacin against E. coli bacteria $4 \mathrm{mg} /$ disk (A), $8 \mathrm{mg} /$ disk (B), Amikacin $0.1 \mathrm{mg} /$ disk (C), Aqua pro injection (D), DMSO (E)

Note: Comparison 25:75 (I), Comparison 50:50 (II), Comparison 75:25 (III)

Table 4. The results of the antibacterial activity of the combination of peppermint leaf ethanol extract $4 \mathrm{mg} /$ disk and amikacin $0.1 \mathrm{mg} /$ disk

\begin{tabular}{lccc}
\hline \multicolumn{1}{c}{ Test Material } & $\begin{array}{c}\text { K. pneumoniae } \\
\text { inhibition zone } \\
\text { diameter }(\mathbf{m m})\end{array}$ & $\begin{array}{c}\text { S. aureus inhibition } \\
\text { zone diameter }(\mathbf{m m})\end{array}$ & $\begin{array}{c}\text { E. coli inhibition } \\
\text { zone diameter } \\
\text { (mm) }\end{array}$ \\
\hline $\begin{array}{l}\text { Extract 4 mg/disk + Amikacin } \\
0.1 \mathrm{mg} / \text { disk (25:75) }\end{array}$ & $36.25 \pm 2.5$ & $27.25 \pm 1.71$ & $26.75 \pm 1.5$ \\
\hline $\begin{array}{l}\text { Extract 4 mg/disk + Amikacin } \\
0.1 \mathrm{mg} / \text { disk (50:50) }\end{array}$ & $32 \pm 1.5$ & $27.25 \pm 1.89$ & $28 \pm 1.16$ \\
\hline $\begin{array}{l}\text { Extract 4 mg/disk + Amikacin } \\
0.1 \mathrm{mg} / \text { disk (75:25) }\end{array}$ & $34 \pm 1.71$ & $26 \pm 1.41$ & $26.75 \pm 2.62$ \\
\hline Amikacin 0.1mg/disk & $30 \pm 0$ & $20 \pm 0$ & $20 \pm 0$ \\
\hline DMSO & 6 & 6 & 6 \\
\hline Aqua pro injection & 6 & 6 & 6 \\
\hline
\end{tabular}

\section{Note: Inhibition zone diameter including disk diameter $(6 \mathrm{~mm})$, is the average of 4} times of replication

Table 5. The results of the antibacterial activity test of a combination of peppermint leaf ethanol extract $8 \mathrm{mg} /$ disk and amikacin $0.1 \mathrm{mg} /$ disk

\begin{tabular}{lccc}
\hline \multicolumn{1}{c}{ Test Material } & $\begin{array}{c}\text { K. pneumoniae } \\
\text { inhibition zone } \\
\text { diameter }(\mathbf{m m})\end{array}$ & $\begin{array}{c}\text { S. aureus inhibition } \\
\text { zone diameter }(\mathbf{m m})\end{array}$ & $\begin{array}{c}\text { E. coli inhibition } \\
\text { zone diameter } \\
\text { (mm) }\end{array}$ \\
\hline $\begin{array}{l}\text { Extract 8 mg/disk + Amikacin } \\
\text { 0.1mg/disk (25:75) }\end{array}$ & $39.75 \pm 2.36$ & $31.5 \pm 1.73$ & $31.5 \pm 1.73$ \\
\hline $\begin{array}{l}\text { Extract 8 mg/disk + Amikacin } \\
\text { 0.1mg/disk (50:50) }\end{array}$ & $375 \pm 2.45$ & $32.75 \pm 1.5$ & $31 \pm 0.82$ \\
\hline $\begin{array}{l}\text { Extract 8 mg/disk + Amikacin } \\
0.1 \mathrm{mg} / \text { disk (75:25) }\end{array}$ & $40 \pm 1.63$ & $29.5 \pm 0.58$ & $29 \pm 1.15$ \\
\hline Amikacin 0.1mg/disk & $30 \pm 0$ & $20 \pm 0$ & $20 \pm 0$ \\
\hline DMSO & 6 & 6 & 6 \\
\hline Aqua pro injection & 6 & 6 & 6 \\
\hline
\end{tabular}

Note: Inhibition zone diameter including disk diameter $(6 \mathrm{~mm})$, is the average of 4 times of replication 
The synergistic effect of the combination of peppermint leaf ethanol extract and amikacin in inhibiting bacterial growth showed a mutually supportive effect between the two. Research conducted by Pramila et al., 2012 showed Peppermint leaf extract compounds that can inhibit bacterial growth is flavonoid compounds and tannins. The combination of antibiotics and flavonoid compounds can provide a synergistic effect in inhibiting bacterial growth because flavonoid compounds are the largest group of phenolic compounds so that when combined with antibiotics can increase the diameter of the inhibition zone in inhibiting bacterial growth. (Amin et al., 2016). The mechanism of action of amikacin, which is an aminoglycoside group, is to inhibit protein biosynthesis by irreversibly binding aminoglycosides to the 30S subunit of the bacterial ribosome (Katzung and Bertram, 2004), so that it can inhibit the function of the 30S subunit of the bacterial ribosome and will cause the bacteria to die. The addition of extract to the use of amikacin can increase activity as an antibacterial by producing a larger diameter of the inhibition zone without the combination.

The data calculated using the t-test showed that the significance value obtained was $0.000<0.05$. It could be concluded that there was a significant difference in the administration of each concentration to the resulting inhibition zone. The results showed a synergistic effect with the largest diameter of the inhibitory zone at a ratio of 25:75 with a concentration of $200 \mathrm{mg} / \mathrm{mL}$, which was $36.25 \pm 2.5 \mathrm{~mm}$ on Klebsiella pneumoniae bacteria, which before combined the diameter of the inhibition zone was $18 \pm 1.63 \mathrm{~mm}$. Meanwhile, at a concentration of $400 \mathrm{mg} / \mathrm{mL}$, the diameter of the largest inhibition zone was $40 \pm 1.63 \mathrm{~mm}$ in Klebsiella pneumoniae bacteria with a ratio of 75:25 which before combined the diameter of the resulting inhibition zone was $20.5 \pm 0.58 \mathrm{~mm}$.

\section{Phytochemical Screening Results}

The purpose of the phytochemical screening test was to determine the content of compounds contained in the ethanol extract of peppermint leaves. This phytochemical screening test was carried out using the tube method, namely by using several color reagents (Simaremartye, 2014). The results of phytochemical screening of peppermint leaf ethanol extract showed negative results on saponins and steroids, this was because the glycosyl groups on saponins which act as polar groups were not active on the surface so that when shaken with water the saponins would not show foam, while on steroids the color changed to green. caused by oxidation but the results did not show a color change so that there was no color change due to the absence of oxidation of steroid compounds through the formation of conjugated double bonds (Risky and Suyatno, 2014).

Positive results were shown on alkaloids, phenolic compounds, flavonoids, tannins, and triterpenoids. In the alkaloid tested using Meyer's reagent a white precipitate will form and with Dragendorff's reagent a red color will be formed, this is due to the presence of an alkaloid complex with potassium so that a precipitate will form (Marliana and Suryanti, 2015). The test results on phenolic showed positive in the presence of black color in the reaction tube, the black color formed was due to the reaction of $\mathrm{FeCl}_{3}$ with the aromatic $-\mathrm{OH}$ group. In the flavonoid test, the formation of yellow color was due to the reduction by concentrated $\mathrm{HCl}$ with $\mathrm{Mg}$ powder (Minarno, 2015). Test on tannins using sodium chloride and gelatin, the formation of a precipitate due to the reaction between tannins and gelatin will form a copolymer that is insoluble with water so that it will precipitate protein from gelatin (Datin et al., 2014). Positive results on triterpenoids 
are indicated by a red-brown color due to the addition of $\mathrm{H}_{2} \mathrm{SO}_{4}$ so that a brownish ring is formed in the test solution (Qurrota and Laily, 2011).

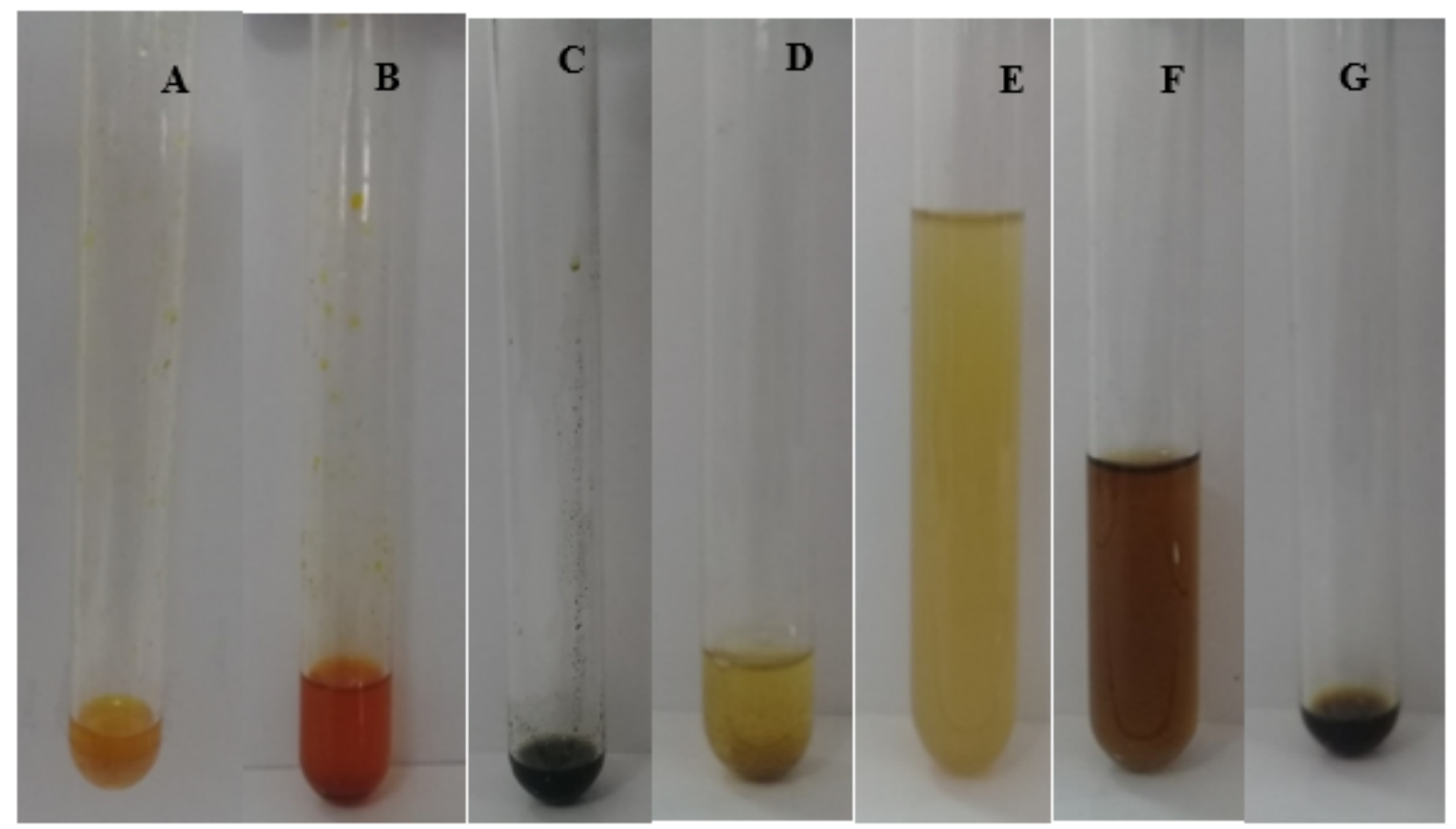

Picture 6. Phytochemical screening test results of ethanol extract of peppermint leaf alkaloids (A, B), phenolics (C), flavonoids (D), saponins (E), tannins (F), steroids (G)

Table 6. Phytochemical screening results of peppermint leaf ethanol extract

\begin{tabular}{|c|c|c|c|}
\hline Compound & $\begin{array}{c}\text { References } \\
\text { (Pulipati et al., } \\
\text { 2016) }\end{array}$ & $\begin{array}{c}\text { Phytochemical Screening } \\
\text { Results }\end{array}$ & Derivative Compound \\
\hline Alkaloids & + & $\begin{array}{l}\text { + (With Meyer's reagent a } \\
\text { white precipitate is formed, } \\
\text { with Dragendorff's reagent a } \\
\text { yellow-red precipitate is } \\
\text { formed) }\end{array}$ & Hydrocotyl alkaloids \\
\hline Phenolic & + & $+($ Dark Black $)$ & $\begin{array}{l}\text { Phenolic acid, } \\
\text { chlorogenic, rosmarinic }\end{array}$ \\
\hline Flavonoids & + & $+($ Yellow $)$ & Quercetin, mentoside, \\
\hline Saponins & _ & _ (No foam formed) & isoroifolin, vitamin $\mathrm{K}$, \\
\hline Tannins & + & $+($ Chocolate precipitate) & eugenol, thymol, rutin \\
\hline $\begin{array}{l}\text { Steroids / } \\
\text { Triterpenoids }\end{array}$ & $+/+$ & $-/+($ Red-brown $)$ & $\begin{array}{l}\text { Squalene, urosolic acid, } \\
\text { a-amyrin }\end{array}$ \\
\hline
\end{tabular}

\section{Description: + (positive), - (negative)}

The results of the research conducted by Pulipati et al., (2016) showed Peppermint leaf ethanol extract contains alkaloids, phenolic compounds, flavonoids, tannins, steroids, and triterpenoids, while the results are negative for saponins. Research conducted by Pulipati et al., (2016) compared to the test results in this study, the ethanol extract of peppermint leaves was almost the same but in this study, there were no steroid compounds, this was due to differences in the reagents used.

The mechanism of action of alkaloids as an antibacterial is by interfering with the constituent components of peptidoglycan in bacterial cells so that the cell wall layer is 
not fully formed and can cause cell death (Darsana et al., 2012). The mechanism of action of phenolics in killing microorganisms is by denaturing cell proteins. The hydrogen bonds formed between phenol and protein cause the protein structure to be damaged. The hydrogen bonds will affect the permeability of the cell wall and cytoplasmic membrane. Permeability of cell walls and cytoplasmic membranes that are disrupted can cause an imbalance of macromolecules and ions in the cell so that the cell becomes lysed (Poongothai and Rajan, 2013).

The mechanism of action of flavonoids in inhibiting bacterial growth is divided into three, namely inhibiting nucleic acid synthesis, inhibiting cell membrane function, and inhibiting energy metabolism. The antibacterial mechanism of flavonoid compounds inhibiting nucleic acid synthesis is the location of the hydroxyl group at the $2^{\prime}, 4^{\prime}$ or $2^{\prime}, 6^{\prime}$ dihydroxylation position on rings $B$ and 5,7 dihydroxylation on ring A plays an important role in antibacterial activity. Flavonoids cause damage to the permeability of bacterial cell walls, microsomes, and lysosomes as a result of interactions between flavonoids and bacterial DNA (Hendra et al., 2011).

The mechanism of action of flavonoids in inhibiting cell membrane function is to form complex compounds with extracellular proteins so that they can damage bacterial cell membranes and are followed by the release of intracellular compounds (Nuria et al., 2009). Flavonoids can inhibit energy metabolism by inhibiting the use of oxygen by bacteria. Flavonoids will inhibit cytochrome $\mathrm{C}$ reductase so that the formation of metabolism is inhibited, energy is needed by bacteria for macromolecular biosynthesis (Rao, 2013).

The mechanism of action of tannins as an antibacterial is by inhibiting the enzyme reverse transcriptase and DNA topoisomerase so that bacterial cells cannot be formed (Concerned et al., 2018). The mechanism of triterpenoids as an antibacterial is related to lipid membranes and sensitivity to triterpenoid components that cause leakage in lysosomes. Triterpenoids can interact with cell phospholipid membranes which are permeable to lipophilic compounds, causing decreased membrane integrity and cell membrane morphology to change which causes cell brittleness and lysis (Puspita, 2011).

\section{CONCLUSION}

Based on the results of the study, it can be concluded that the peppermint leaf ethanol extract has antibacterial activity against Klebsiella pneumoniae, Staphylococcus aureus, and Escherichia coli bacteria, the combination of peppermint leaf ethanol extract and amikacin has a synergistic effect or a unidirectional effect indicated by the diameter of the combined inhibition zone is greater than which is without combination. Peppermint leaf ethanol extract contains alkaloids, phenolic compounds, flavonoids, tannins, and triterpenoids.

\section{REFERENCES}

Al-sum BA and Al-arfaj AA, 2013, Antimicrobial Activity of the Aqueous Extract of Mint Plant, Science Journal of Clinical Medicine, 2 (3), 110-113.

Amin MU, Khurram M., Khan TA, Faidah HS, Shah ZU, Rahman SU, Haseeb A., Ilyas M., Ullah N., Muhammad S., Khayam U. and Iriti M., 2016, Effects of Luteolin and 
Quercetin in Combination with Some Conventional Antibiotics against MethicillinResistant Staphylococcus aureus, International Journal of Molecular Sciences, 116.

An D., Sukmawati N., Hayati EK, Muti R., 2014, Recovery (Paederia foetida Linn.) Using the Brine Shrimp Lethality Test Method, Alchemy, 3 (2), 189-193.

Ansel HC, 1989, Introduction to Pharmaceutical Preparation Form IV, Ibrahim, F., ed., UI Press, Jakarta.

Cahyono W. and Indrayudha P., 2013, Antibacterial Activity of Combination of Ethanol Extract of Red Betel Leaf (Piper crocatum Ruiz and Pav) and Chloramphenicol Against Salmonella typhi, Shigella dysenteriae, and Staphylococcus aureus and their bioautography. Muhammadiyah Surakarta university.

Darsana 0., Besung NK and Mahatmi H., 2012, Potential of Binahong Leaf (Anredera Cordifolia ( Tenore ) Steenis ) in Inhibiting the Growth of Escherichia coli Bacteria In Vitro, Indonesia Medicus Veterinus, 1 (3), 337-351.

Diniatik, 2015, Determination of Total Flavonoid Levels of Kepel Leaf Ethanolic Extract (Stelechocarpus burahol (Bl.) Hook f. \& Th.) Using Spectrophotometric Methods, Kartika Scientific Journal of Pharmacy, II (1), 1-5.

Ernaeni Y., Supriyadi A. and Rinto, 2012, Effect of Solvent Type on Chlorophyll and Phytochemical Compounds of Kiambang Leaves (Salvinia molesta Mitchell) From Swamp Waters, Fishtech, 1 (01), 1-13.

Furlan MR, Olavo A. and Jorge C., 2010, Antimicrobial activity of Mentha piperita L. against Candida spp., Braz Dent Sci, 13 (1), 4-9.

Grayson ML, Cosgrove SE, Crowe SM, Hope W., McCarthy JS, Mills J., Mouton JW and Paterson DL, 2017, Kucers' the use of antibiotics: A clinical review of antibacterial, antifungal, antiparasitic, and antiviral drugs, seventh editions,

Handoko R., Haryoto and Peni Indrayudha, 2013, Antibacterial Activity of Ethanol Extract of Sala (Cynometra ramiflora L.) Leaves Against Staphylococcus epidermidis, Pseudomonas aeruginosa, and Klebsiella pneumoniae and their bioautography. Muhammadiyah Surakarta university.

Hanik I., Yuliani R. and Indrayudha P., 2012, Antibacterial Activity of Combination of Ethanol Extract of Pomegranate Peel (Punica granatum L.) and Chloramphenicol Against Sensitive and Multiresistant Staphylococcus aureus. Muhammadiyah Surakarta university.

Hendra R., Ahmad S., Sukari A. and Shukor MY, 2011, Flavonoid Analyses and Antimicrobial Activity of Various Parts of Phaleria macrocarpa ( Scheff .) Boerl Fruit, International Journal of Molecular Sciences, 2 (12), 3422-3431. 
Jawetz E., Melnick JL and Adelberg EA, 2005, Medical Microbiology, XXII. Mudihardi, E., Kuntaman, Wasito, EB, Mertaniasih, NM \& Harsono, S., Alimsardjono, L., eds., Salemba Medika Publisher, Jakarta.

Marliana SD and Suryanti V., 2015, Phytochemical Screening and Thin Layer Chromatography Analysis of Chemical Components of Chayote (Sechium edule Jacq. Swartz.), Biopharmaceutical, 3 (1), 26-31.

Minarno EB, 2015, Phytochemical Screening and Total Flavonoid Content in Carica pubescens Lenne \& K. Koch Fruits in the Bromo, Cangar and Dieng Plateau Regions, El-Hayah, 5 (2), 73-82.

Mohamed M.., 2013, The Antibacterial Effect of Some Medicinal Plant Extracts and Their Synergistic Effect with Antibiotic and Non-antibiotic Drug, March, 134.

Nurhidayati S., Faturrahman and Ghazali M., 2015, Detection of Pathogenic Bacteria Associated with Kappaphycus alvarezii (Doty) with Ice-Ice Disease, Journal of Environmental Science and Technology, 1 (2), 24-30.

Nuria MC, Faizatun A. and Sumantri, 2009, Antibacterial Activity Test of Ethanol Extract of Jatropha Leaves (Jatropha curcas L) Against Staphylococcus aureus ATCC 25923, Escherichia coli ATCC 25922, and Salmonella typhi ATCC 1408, Mediagro, 5 (2), $26-37$.

Poongothai P. and Rajan S., 2013, Original Research Article Antibacterial Properties of Mangifera indica flower extracts on Uropathogenic Escherichia coli, International Journal of Current Mycrobiology and Applied Sciences, 2 (12), 104-111.

Pramila, DM, Xavier, R, Marimuthu, K, Kathiresan, S, Khoo, ML, Senthilkumar, M., Sathya, K., Sreeramanan S., 2012, Phytochemical analysis and antimicrobial potential of methanolic leaf extract of peppermint (Mentha piperita : Lamiaceae), Journal of Medicinal Plants Research, 6 (3), 331-335.

Concerned AI, Krisnawati, Dwi Rahayu AA, Nugraheni A. and Samawandana G., 2018, Phytochemical Test and Antibacterial Activity of Pranajiwa Plants (Euchresta horsfieldii (Lesch.) Benn.), Journal of Forestry Science, 1 (12), 223-233.

Pulipati S., Koushik O. and Babu P., 2016, Phytochemical Analysis and Antibacterial Efficacy of Mentha piperita (L) Ethanolic Leaf Extract against Clinical Isolates of Uropathogens, British Microbiology Research Journal, 13 (6), 1-5.

Puspita F., 2011, Extraction of Antimicrobial Active Substances from Iodine Plants (Jatropha multifida Linn) as Alternative Raw Materials for Natural Antibiotics.

Qurrota A. and Laily AN, 2011, Phytochemical Analysis of Papaya Leaves (Carica papaya L.) at the Research Institute for Various Nuts and Tubers, Kendalpayak, Malang, PKHL, 20 (03), 134-137. 
Raghavan R., Devi MPS, Varghese M., Joseph A., Madhavan SS and Sreedevi PV, 2018, Effectiveness of Mentha piperita leaf extracts against oral pathogens: An in vitro study, Journal of Contemporary Dental Practice, 19 (9), 1042 -1046.

Rao KB, 2013, In Vitro Evaluation Of Antibacterial Activity Of Five Indigenous Plants Extract Against Five Bacterial Pathogens Of Human, International Journal of Pharmacy and Pharmaceutical Sciences, 5 (4), 679-684.

Risky AT and Suyatno, 2014, Antioxidant And Anticancer Activities Of Methanol Extract Of The Adiantum philippensis L., UNESA Journal of Chemistry, 3 (1), 89-95.

Simaremartye ES, 2014, Phytochemical Screening of Itchy Leaf Ethanol Extract (Laportea decumana (Roxb.) Wedd), Pharmacy, 11 (01), 98-107.

Stefanović O. and Comic L., 2012, Synergistic antibacterial interaction between Melissa officinalis extracts and antibiotics, Journal of Applied Pharmaceutical Science, 2 (1), 1-5.

Ventola C., 2015, The antibiotic resistance crisis: Causes and threats., P \& T: a peerreviewed journal for formulary management, 40 (4), 277-83. 